\title{
OPTIMASI PRODUKSI KITOSAN LARUT AIR MENGGUNAKAN METODE HIDROLISIS BERTEKANAN
}

\author{
Sudianto*, Sugeng Heri Suseno, Pipih Suptijah \\ Departemen Teknologi Hasil Perairan, IPB University, Jalan Agatis, Kampus IPB Dramaga, Bogor \\ *Korespondensi: sudiansar14@gmail.com \\ Diterima: 10 Juli 2020/Disetujui: 06 November 2020
}

Cara sitasi: Sudianto, Suseno SH, Suptijah P. 2020. Optimasi produksi kitosan larut air menggunakan metode hidrolisis bertekanan. Jurnal Pengolahan Hasil Perikanan Indonesia. 23(3): 441-446.

\begin{abstract}
Abstrak
Modifikasi untuk produksi kitosan terus dilakukan sehingga menghasilkan berbagai bentuk kitosan baik itu berupa serpihan, butiran, membran maupun gel. Diversifikasi turunan dari kitosan masih harus dilakukan, misalnya produk diversifikasi kitosan yang telah ada seperti glukosamin dan perlu dilakukan produksi kitosan larut air untuk menambah diversifikasi dan memperluas kegunaan produk kitosan. Tujuan dari penelitian ini adalah untuk menentukan optimasi konsentrasi larutan asam klorida dan rasio kitosan dalam memproduksi kitosan larut air menggunakan tekanan hidrolisis dengan metode Response Surface Methodology (RSM) Box Behnken. Perlakuan kondisi produksi kitosan larut air yang direkomendasikan RSM adalah konsentrasi $\mathrm{HCl}$ 1,75\%, rasio kitosan 1:10 dan waktu pemanasan selama 45 menit. Karakteristik kitosan larut air pada kondisi optimum diperoleh rendemen $80 \%, \mathrm{pH}$ 6, kadar air 41,9\%, kadar abu 1,33\%, kadar nitrogen 3,28\%, kelarutan 66,38\%.
\end{abstract}

Kata kunci: kitosan larut air, limbah udang, Response Surface Methodology

\section{Optimatization of Production Water Soluble Chitosan Using Pressurized Hidrolysis Method}

\begin{abstract}
Modifications for chitosan production continue to be done so as to produce various forms of chitosan in the form of chips, granules, membranes and gels. Meanwhile, to diversify the derivatives from chitosan still needs to be done, existing chi-tosan diversified products such as glucosamine and water soluble chitosan production needs to be done to increase diversifi-cation and expand the use of chitosan products. The purpose of this study was to determine the optimum condition for the production of water soluble chitosan using hydrolysis pressure by the Box-Behnken Methodology Response Surface (RSM-BoxBehnken). The RSM-Box Behnken recommended optimum condition for production of water soluble chitosan at $1.75 \%$ $\mathrm{HCl}$ concentration, 1:10 ratio of chitosan, for 45 minutes (desirability 76.1\%) resulting in the yield of 79.5\%, $\mathrm{pH}$ of 5.93 , water content of $25.45 \%$, ash content of $1.33 \%$, nitrogen level of $4.78 \%$ and solubility of chitosan of $42.66 \%$. Production of water sol-uble chitosan using the optimum conditions from the RSM recommendation obtained yield of $80 \%, \mathrm{pH}$ of 6.0 , water content of $41.9 \%$, ash content of $1.29 \%$, nitrogen level of $3.28 \%$ and solubility of chitosan of $66.38 \%$.
\end{abstract}

Keywords: Response Surface Methodology, shrimp waste, water soluble chitosan. 


\section{PENDAHULUAN}

Kitosan adalah produk deasetilasi dari polisakarida kitin yang diproduksi dari berbagai organisme seperti cangkang udang, kepiting, rajungan, lobster, serta dinding sel dari jamur (Tao et al. 2013). Kitosan dapat digunakan sebagai bahan minuman kesehatan (Rochima 2016), absorben logam berat (Stevano et al. 2016), menurunkan kandungan logam berat (Sulastri et al. 2016), penguat plastik (Selpiana et al. 2016), antibakteri (Sahariah et al. 2014), edible fim (Sofia et al. 2016), penghantar dan pelindung obat (Akmarina dan Sriwidodo 2016), antifungal, antibakteri dan antimalaria (Marieta et al. 2019), biokoagulan (Bija et al. 2020), dimanfaatkan dalam daur ulang air (Ratnawulan et al. 2018) dan salah satu alternatif membran penukar proton (Ibrahim et al. 2020). Kitosan diproduksi dari bahan cangkang krustasea melalui tahap penghilangan mineral (demineralisasi), penghilangan protein (deproteinasi), pada kedua tahap ini cangkang krustasea akan menghasilkan kitin. Selanjutnya, produksi kitosan dilakukan dengan penghilangan gugus asetilnya atau tahap deasetilasi. Derajat deasetilasi adalah salah satu parameter penting untuk mutu kitosan.

Saleh et al. (2017) berhasil menyintesis kitosan larut air dari limbah cangkang udang dan dimanfaatkan sebagai inhibitor korosi. Ernawati et al. (2014) memanfaatkan limbah krustasea untuk memproduksi glukosamin hidroklorida dengan tekanan hidrolisis dengan perbandingan $\mathrm{HCl} \mathrm{1:9} \mathrm{dengan} \mathrm{waktu}$ pemanasan 30 menit-120 menit menghasilkan karakteristik glukosamin yang berbeda. Tao et al. (2013) menyatakan bahwa kitosan larut air dapat menurunkan lemak darah. Park et al. (2015) mengungkapkan kitosan larut air dapat digunakan untuk penyembuhan luka.

Modifikasi untuk produksi kitosan terus dilakukan sehingga menghasilkan berbagai bentuk kitosan baik itu berupa serpihan, butiran, membran maupun gel. Sedangkan untuk diversifikasi turunan dari kitosan masih harus dilakukan, produk diversifikasi kitosan yang telah ada seperti glukosamin dan perlu dilakukan produksi kitosan larut air untuk menambah diversifikasi dan memperluas kegunaan produk kitosan. Produk turunan kitosan seperti nano kitosan dapat diaplikasikan untuk lapisan aktif pada mikrobiologi ikan (Abdou et al. 2012), anti mikroba (Martins et al. 2014). Metode pemanasan dengan perlakuan asam yang tinggi serta diruang terbuka tanpa tekanan tertutup kurang dianjurkan karena tidak efektif dan kurang aman.

Produksi kitosan larut air akan efektif dengan panci presto dan bisa menekan biaya yang lebih murah dengan dengan metode tekanan yang tertutup. Mengacu dari hal itu dilakukan penelitian mengenai pembuatan kitosan larut air dengan konsentrasi asam rendah menggunakan panci presto. Tujuan dari penelitian ini adalah untuk menentukan optimasi konsentrasi larutan asam klorida dan rasio kitosan dalam memproduksi kitosan larut air menggunakan tekanan hidrolisis dengan metode Response Surface Methodology (RSM).

\section{BAHAN DAN METODE Bahan dan Alat}

Bahan-bahan yang digunakan untuk produksi kitin antara lain: kulit udang yang diperoleh dari perusahaan pengupas kulit udang di Muara Baru; bahan kimia yang digunakan adalah $\mathrm{HCl}$, akuades, IPA (isopropyl alcohol) dan $\mathrm{NaOH}$.

Alat-alat yang digunakan dalam penelitian ini adalah: alat produksi kitosan: tanur, gelas ukur, oven, panci, spektrofotometer, penggiling/grinder, pengaduk, saringan, termometer, panci presto, timbangan digital, $\mathrm{pH}$ meter, kertas saring dan alat FTIR (Fourier Transform Infrared Spectroscopy) merek perkin elmer.

\section{Metode Penelitian}

Penelitian ini dibagi ke dalam dua tahap yaitu pembuatan kitosan dari limbah karapas udang serta pembuatan kitosan larut air dari kitosan yang dihasilkan. Limbah karapas udang dicuci menggunakan air hangat, setelah itu dilakukan pengeringan menggunakan oven, kemudian dilakukan tahap produksi kitosan yang dilakukan dengan proses penguapan panas dari tanur yang disalurkan 
ke jeriken yang diisi karapas udang dan bahan kimia berdasarkan setiap prosesnya. Tahap pertama limbah karapas udang dicuci, setelah itu dilakukan pengeringan. Tahap produksi kitosan yang dilakukan dengan proses penguapan panas dari tanur yang disalurkan ke jeriken yang diisi karapas udang dan bahan kimia berdasarkan setiap prosesnya. Proses kitosan terdiri dari demineralisasi dengan menambah $\mathrm{HCl} 1,5 \mathrm{~N}$ dengan perbandingan $1: 10(\mathrm{~g} / \mathrm{mL})$, selama 1 jam pada suhu $90{ }^{\circ} \mathrm{C}$ supaya mineral-mineral yang masih terkandung dalam kulit udang hilang, terutama kalsium, disebut juga tahap dekalsifikasi, difiltrasi dan proses deasetilasi dengan memanaskan karapas dengan $\mathrm{NaOH}$ $50 \%$ dengan perbandingan $1: 10(\mathrm{~g} / \mathrm{mL})$ pada suhu $130{ }^{\circ} \mathrm{C}$. Setelah itu dilakukan analisis warna, rendemen, derajat putih, kadar abu, kadar air, kadar nitrogen, dan derajat deasetilasi.

Tahap kedua produksi kitosan larut air. Pada tahap ini dilakukan optimasi dengan menggunakan piranti lunak komputer yaitu Program DX 7.0 dengan rancangan RSMBox Behnken. Optimasi kitosan larut air menggunakan metode RSM dilakukan dalam empat tahap, yaitu (1) pembuatan rancangan formulasi dan respon; (2) formulasi; (3) Analisis respon; (4) optimasi. Kemudian dilanjutkan ke tahap verifikasi, sebagai pembuktian terhadap prediksi dari nilai respon solusi formula optimum (Montgomery 2001).

Produksi kitosan larut air dilakukan dengan proseshidrolisiskimiawimenggunakan hidroklorida $(\mathrm{HCl})$ pada tekanan dan suhu yang sama yaitu 0,8 atm $-0,9$ atm dan $110^{\circ} \mathrm{C}$ dengan menggunakan presto. Proses hidrolisis dimulai dengan menambahkan kitosan hasil produksi tahap pertama ke dalam larutan asam klorida dengan perlakuan konsentrasi $\mathrm{HCl}$ dan rasio kitosan yang berbeda yang telah dihasilkan dalam program DX 07 yaitu konsentrasi asam $0,75 \%-1,75 \%$ dengan rasio kitosan 1:8 - 1:10 (g/mL) selama 30-45 menit. Kemudian dilakukan pencucian dengan larutan isopropil alkohol, larutan diendapkan dan disaring kemudian diendapkan kembali dengan isopropil sampai $\mathrm{pH}$ netral, kemudian kitosan larut air dianalisis.

\section{HASIL DAN PEMBAHASAN Uji Mutu Kitosan Kulit Udang}

Proses pembuatan kitosan kulit udang melalui tiga tahap yaitu tahap pertama menghilangkan mineral dalam kulit udang (demineralisasi) dengan larutan $\mathrm{HCl} \mathrm{1,5 \textrm {N }}$ selama 1 jam pada suhu $90{ }^{\circ} \mathrm{C}$, kemudian menghilangkan gugus asetil (deasetilasi) menggunakan $\mathrm{NaOH} 50 \%$ pada suhu $130{ }^{\circ} \mathrm{C}-140{ }^{\circ} \mathrm{C}$. Karakteristik kitosan dapat dilihat pada Table 1 .

Table 1 Shrimp shells chitosan characteristics

\begin{tabular}{lcc}
\hline \multicolumn{1}{c}{ Parameter } & Value & $\begin{array}{c}\text { INS } \\
79492013\end{array}$ \\
\hline Yield(\%) & $15.00 \pm 0.00$ & - \\
Acidity(pH) & $6.00 \pm 0.00$ & 7 \\
Water (\%) & $11.93 \pm 0.06$ & $\leq 12$ \\
Ash (\%) & $2.07 \pm 0.39$ & $\leq 5$ \\
Nitrogen (\%) & $5.58 \pm 0.02$ & $\geq 5$ \\
$\begin{array}{l}\text { Whiteness Index } \\
\text { (\%) }\end{array}$ & $99.90 \pm 0.00$ & - \\
$\begin{array}{l}\text { Deacetilation } \\
\text { Degree (\%) }\end{array}$ & 79,1 & $\geq 75$ \\
\hline \multicolumn{2}{c}{ Rendemen } & Jang dihasilkan
\end{tabular}
penelitian ini berkisar 15\%. Rendemen kitosan yang diperoleh merupakan hasil dari proses deasetilasi, dalam hal ini berhubungan dengan terbuangnya gugus asetil yang terkandung pada kulit udang. Rendemen juga dipengaruhi lama perendaman, semakin lama waktu perendaman maka akan semakin banyak rendemen dari kitosan.

Nilai derajat keasaman kitosan pada pada penelitian ini adalah 6. Hasil dari derajat keasaman tergantung dari optimal tidaknya proses penetralan. Proses penetralan bertujuan untuk menghasilkan kitosan dengan nilai $\mathrm{pH}$ tidak terlalu rendah sehingga mendekati netral, dan dapat membantu proses penghilangan senyawa-senyawa yang menjadi pengotor yang masih terdapat dalam kitosan. Pengukuran kadar air dilakukan karena berkaitan dengan daya simpan kitosan. Nilai kadarair kitosan $11,93 \%$. Nilai kadar air kitosan $11,93 \%$. Pengukuran kadar air dilakukan karena berkaitan dengan daya simpan kitosan. Kadar air kitosan telah memenuhi syarat- 
syarat karakteristik kitosan yaitu $\leq 12 \%$ (SNI 2013). Penyimpanan kitosan dilakukan dalam plastik zip pack, sehingga kelembapannya rendah, dan kadar air yang dihasilkan rendah, dan menunjukkan kualitas yang baik. Nilai kadar abu kitosan 2,07\%. Nilai kadar abu kitosan 2,07\%. Apabila dibandingkan dengan karakteristik abu kitosan yang ditetapkan oleh Standar Nasional Indonesia yaitu $\leq 5 \%$, maka kadar abu kitosan tersebut telah memenuhi standar mutu kitosan. Pencucian yang baik dengan melakukan berulang-ulang pada saat demineralisai sampai mencapai $\mathrm{pH}$ netral menyebabkan komponen mineral berupa kalsium klorida yang sudah larut dan terpisah dari karapas terbuang dengan pada saat pencucian di air mengalir. Kadar nitrogen yang dihasilkan dari penelitian ini adalah 5,58\%. Sifat kitosan dalam berintreaksi dengan gugus lainnya seperti gugus amin $\left(\mathrm{NH}_{2}\right)$ ditentukan dari kadar nitrogen, sehingga reaktivitas yang dimiliki kitosan menjadi tinggi, yang menyebabkan kitosan dapat mengikat air dan larut dalam asam asetat (Rahmania 2011). Derajat putih merupakan parameter mutu fisik yang penting untuk produk kitosan. Nilai derajat putih kitosan 99,9\%, derajat putih kitosan sangat baik, yang mengindikasikan bahwa kandungan pigmen dan protein pengotor telah optimasi dibersihkan, senyawa protein dan pigmen dapat dihilang kan dengan pencucian yang terus menerus dan intensif (Suptijah et al. 2014). Nilai derajat deasetilasi dari kitosan yang diperoleh pada penelitian ini adalah $79,1 \%$ menghasilkan nilai derajat deasetilasi yang telah memenuhi karakteristik kitosan SNI 2013 yaitu $\geq 75 \%$. Peningkatan derajat deasetilasi tergantung pada derajat deasetilasi awal atau derajat deasetilasi kitin. Derajat deasetilasi yang tinggi dipengaruhi oleh proses deasetilasi kitin menjadi kitosan (Cahyono 2018).

\section{Analisis Respons}

Hasil data variabel respons dianalisis oleh program DX 7.0 rancangan RSM-Box Behken untuk mengetahui kecenderungan dari model persamaan polinomial dengan ordo yang sesuai dengan hasil yang diperoleh dari masing-masing respons. Hasil uji respons rendemen kitosan larut air berkisar
80\% sampai $90 \%$. Hasil respons pengukuran derajat keasaman kitosan larut air berkisar 5 sampai 6. Hasil uji respons kadar air kitosan larut air berkisar $12,48 \%$ sampai $41,3 \%$. Hasil respons pengukuran kadar abu kitosan larut air berkisar $0,93 \%$ sampai 2,26\%. Hasil respons pengukuran kadar nitrogen kitosan larut air berkisar 3,79\%

\section{Hasil Optimasi Formula}

Program DX $07.00^{\circ}$ rancangan RSMBox Behnken akan merekomendasikan solusi formula yang optimum dan nilai tingkat yang diinginkan (desirability) yang paling tinggi yaitu 0,831. Formula yang terpilih yaitu konsentrasi $\mathrm{HCl}$ 1,75\%. Rasio kitosan 1:10 dan waktu pengolahan selama 45 menit. Formula ini diprediksi akan menghasilkan rendemen sebesar 79,75\%, derajat keasaman sebesar 5,93, kadar air sebesar 25,43\%, kadar abu 1,33\%, kadar nitrogen sebesar $4,78 \%$ dan kelarutan sebesar $42 \%$.

\section{Hasil Verifikasi Nilai Prediksi Model}

Pada tahapan verifikasi nilai respons aktual yang diperoleh dibandingkan dengan nilai respons prediksi hasil rekomendasi RSM-Box Behnken program DX 07.00. Model kondisi produksi kitosan larut air yang optimal dilakukan verifikasi dan dibandingkan dengan nilai prediksi disajikan pada Table 2 .

Table 2 menunjukkan bahwa hasil verifikasi respons solusi formula terpilih Program DX 07.00 rancangan RSM-Box Behnken untuk respons rendemen, derajat keasaman, kadar air, kadar abu, kadar nitrogen dan kelarutan masih memenuhi nilai yang diprediksikan karena nilainya berada pada kisaran 95\% CI low - 95\% CI high dan 95\% PI low - 95\% PI high. Hal ini menunjukkan bahwa solusi formula yang diprediksikan oleh Program DX 07.00 rancangan RSMBox Behnken sesuai dengan hasil uji respons aktual yang dilakukan hanya pada kadar air, kadar nitrogen dan kelarutan berada di luar kisaran 95\% CI low - 95\% CI high.

\section{KESIMPULAN}

Berdasarkan parameter kitosan larut air dan grafik tiga dimensi dari RSM Box Behken yang dihasilkan perlakuan konsentrasi $\mathrm{HCl}$ 
Tabel 2 Value of response predicted and verified

\begin{tabular}{lrrrrrr}
\hline \multirow{2}{*}{ Response } & \multirow{2}{*}{ Predicted } & \multirow{2}{*}{ Verified } & 95\%CI* & 95\%CI* & 95\% $\mathrm{PI}^{\star *}$ & \multicolumn{2}{c}{$95 \% \mathrm{PI}^{\star *}$} \\
& & & & \multicolumn{1}{c}{ High } & Low & \multicolumn{1}{c}{ High } \\
\hline Yield (\%) & 79.75 & $80 \pm 0.00$ & 76.92 & 82.58 & 74.63 & 84.87 \\
Acidity & 5.93 & $6 . \pm 0.00$ & 5.66 & 6.20 & 5.45 & 6.42 \\
Water Content (\%) & 25.43 & $41.9 \pm 2.67$ & 12.49 & 38.37 & 2.06 & 48.81 \\
Ash Content (\%) & 1.33 & $1.29 \pm 0.20$ & 0.71 & 1.95 & 0.52 & 2.14 \\
Nitrogen Content(\%) & 4.78 & $3.28 \pm 0.01$ & 3.88 & 5.69 & 3.15 & 6.42 \\
Solubility (\%) & 42.66 & $66.38 \pm 0.00$ & 26.33 & 59.00 & 13.15 & 72.18 \\
\hline
\end{tabular}

Note: ${ }^{*}$ Confident Interval; ${ }^{* *}$ Prediction Interval

$1,75 \%$, rasio kitosan $1: 10(\mathrm{~g} / \mathrm{mL})$ dan waktu 45 menit adalah kondisi optimum pada penelitian ini, dan karakteristik kitosan larut air pada kondisi optimum dengan karateristik hasil verifikasi adalah rendemen $80 \%, \mathrm{pH}$ 6, kadar air $41,9 \%$, kadar abu $1,33 \%$, kadar nitrogen $1,33 \%$ dan kadar kelarutan $66,38 \%$. Produksi kitosan larut air menggunakan panci presto dapat digunakan.

\section{DATA PENDUKUNG}

Data pendukung dari penelitian dapat diakses pada laman web ojs artikel ini.

\section{DAFTAR PUSTAKA}

Abdou ES, Osheba AS, Sorour MA. 2012. Effect of chitosan-nanoparicles as active coating on microbilogical characteristics of fish fingers. International Journal of Applied Science and Technology.2(7): 158169.

Akmarina CA, Sriwidodo. 2016. Aplikasi Kitosan dalam Bidang Farmasetik. Jurnal Farmaka.14(12): .

Bija S, Yulma, Imra, Aldian, Maulana A, Rozi A. 2020. Sintesis biokoagulan berbasisi kitosan limbah sisik ikan bandeng dan aplikasinya terhadap nilai BOD dan COD limbah tahu di Kota Tarakan. Jurnal Pengolahan Hasil Perikanan Indonesia. 23(1): 86-92.

[BSN] Badan Standardisasi Nasional. 2013. SNI 7949: 2013 tentang Kitosan Syarat Mutu dan Pengolahan. Jakarta (ID): Badan Standardisasi Nasional.

Cahyono E. 2018. Karakteristik kitosan dari limbah cangkang udang windu. Jurnal Akuatika Indonesia. 3(2): 96-102.
Ibrahim B, Uju, Soleh AM. 2020. Kinerja membran komposit kitosan-karagenan pada sistem Microbial Fuel Cell dalam menghasilkan biolistrik dari limbah pemindangan ikan. Jurnal Pengolahan Hasil Perikanan Indonesia. 23 (1): 137 146.

Marieta A, Ida M. 2019. Berbagai aktivitas farmakologi dari senyawa kitosan. Jurnal Farmaka. 17 (2): 105-110.

Martins AF, Facchi SP, Folman. 2014. Antimicrobial activity of chitosan derivatives containing $\mathrm{n}$-quaternized moeities in its backbone. International Journal of Molecular Sciences. 2080020832.

Montgomery DC. 2001. Design and analysis of experimental. John Wiley \& Sons Inc, New York.

Park SC, Nam JP, Kim JH, Kim YM, Nah JW, Jang MK. 2015. Antimicrobial action of water soluble $\beta$-chitosan against clinical multi-drug resistant bacteria. Journal Molecular Sciences. 16(4): 7995-8007.

Ratnawulan A, Nooe E, Suptijah P. 2018. Pemanfaatan kitosan dalam daur ulang air sebagai aplikasi teknik produksi bersih. Jurnal Pengolahan Hasil Perikanan Indonesia. 21 (2): 276-286.

Rochima E. 2014. Kajian pemanfaatan limbah rajungan dan aplikasinya untuk bahan minuman kesehatan berbasis kitosan. Jurnal Akuatika.V(1): 71-82.

Sahariah P, Gawarre VS, Lieder R. 2014. The effect of subtituent, degree of acetylation and positioning of the cationic charge on the antibacterial activity of quarternary chitosan derivatives. Journal Marine 
Drugs. 12 (8): 4635-4658.

Saleh CW, Harmami, Ulfin I. 2017. Pengendalian korosi menggunakan inhibitor kitosan larut air untuk baja lunak dalam media HCl 1M. Jurnal Sains dan Seni ITS. 6(1): C-1-C-4.

Selpiana, Patricia, Cindy PA. 2016. Pengaruh penambahan kitosan dan gliserol pada pembuatan bioplastik dari ampas tebu dan ampas tahu. Jurnal Teknik Kimia. 22(1): 57-64.

Sofia I, Hastami M, Norma Y. 2016. Pembuatan dan kajian sifat-sifat fisikokimia, mekanikal, dan fungsional edible film dari kitosan udang windu. Jurnal Bahan Alam Terbarukan. 5(2) 54-60.
Stevano VM, Bayu A, Isna S. 2016. Pemanfaatan kitosan dari limbah cangkang bekicot sebagai adsorben logam berat sen. Jurnal Konversi 5(1): 22-26.

Suptijah P. Ibrahim B, Ernawati. 2014. Pemanfatan limbah krustasea dalam pembuatan glukosamin hidroklorida (GlcN HCl) dengan metode autoklaf. Jurnal Teknologi Perikanan dan Kelautan. 5(2): 171-179.

Tao Y, Zhang HL, Hu YM, Wan S, Su ZQ. 2013. Preparation of chitosan and water-soluble chitosan microspheres via spray-drying method to lower blood lipids in rats with high-fat diets. International Journal of Molecular Sciences. 14(2): 4174-4184. 